\title{
Discovery of a mid-latitude sympatric area for two Southern Hemisphere blue whale subspecies
}

\author{
Flore Samaran ${ }^{1, *}$, Olivier Adam ${ }^{2}$, Christophe Guinet $^{1}$ \\ ${ }^{1}$ Centre d'Études Biologiques de Chizé, Centre National de la Recherche Scientifique (CNRS) - UPR 1934, \\ Villiers en Bois 79360, France \\ ${ }^{2}$ Centre de Neurosciences Paris-Sud, CNRS - UPR 8620, University of Paris Sud Bât 446, Orsay 91 405, France
}

\begin{abstract}
In the Southern Indian Ocean, 2 subspecies of blue whales Balaenoptera musculus spp. occur, the Antarctic B. m. intermedia and the pygmy blue whale B. m. brevicauda. Until the present study was conducted it was assumed that the distribution of these 2 subspecies was delimited by the Antarctic Convergence $\left(52^{\circ}\right.$ to $\left.56^{\circ} \mathrm{S}\right)$ during the austral summer. Here, we report results from the first year-long, continuous acoustic monitoring of blue whales in mid-latitude waters off the Crozet Islands $\left(46^{\circ} 25^{\prime} \mathrm{S}, 51^{\circ} 40^{\prime} \mathrm{E}\right)$. Using acoustic data from an International Monitoring System hydroacoustic station, we found that Antarctic and pygmy blue whales occur sympatrically in this area based on detection of their stereotyped calls. Antarctic blue whale calls were recorded year-round, indicating continuous presence in the region, which contradicts the migration paradigm attributed to this subspecies. Three geographically distinct types of pygmy blue whale calls were recorded during the summer and autumn only. The Madagascan call type was the most frequently recorded, while Sri Lankan and Australian call types recorded in this area suggest basin-scale longitudinal and latitudinal movements. During spring and summer, blue whale calls were often associated with higher frequency sounds (D calls), which have been attributed to feeding activity. The summer co-occurrence of blue whale subspecies highlights the importance of this productive sub-Antarctic area as a blue whale hotspot and provides new insights into blue whale seasonal distribution and segregation.
\end{abstract}

KEY WORDS: Blue whale subspecies $\cdot$ Balaenoptera musculus intermedia $\cdot$ Balaenoptera musculus brevicauda $\cdot$ Southern Indian Ocean $\cdot$ Bioacoustics $\cdot$ Sympatry

\section{INTRODUCTION}

The blue whale Balaenoptera musculus spp. (Linnaeus 1758) is one of the most critically endangered marine species and may still be on the brink of biological extinction. In the Southern Hemisphere, overexploitation during the 20th century reduced populations to less than $1 \%$ of the levels prior to harvesting (Branch et al. 2004). Cessation of commercial whaling in the mid-1960s and the establishment of whale sanctuaries in the Indian and Southern Oceans in 1979 and 1994, respectively, have protected these species from complete extinction (Clapham et al. 1999). Paradoxically, data from whaling expeditions have provided unique information on blue whale biology (Lockyer 1976), ecology (Kawamura 1994), subspecies identification (Ichihara 1966), stock repartition (Gambell
1976), historical abundance (Branch et al. 2004) and distribution and movements (Mackintosh 1966). In the Southern Hemisphere, 2 recognized blue whale subspecies occur (Rice 1998) which can be distinguished morphologically (Ichihara 1966, Branch et al. 2007b), genetically (LeDuc et al. 2007) and acoustically from one another (Ljungblad et al. 1998, McDonald et al. 2006). The Antarctic or 'true' blue whale B. m. intermedia is found in the waters of the Southern Ocean, while the pygmy blue whale $B . \mathrm{m}$. brevicauda is reported to be very uncommon at high latitudes (above $60^{\circ} \mathrm{S}$; Ichihara 1966, Kato et al. 1995, Branch et al. 2007a,b). In the Indian Ocean, the pygmy blue whale has been further subdivided into 3 independent subpopulations in the northwest Indian Ocean, sub-Antarctic and Australian regions (Zemsky \& Sazhinov 1982). In the northern Indian Ocean, another blue whale sub- 
species, B. m. indica (Blyth 1859), has been suggested to be a separate subspecies from the pygmy blue whale on the basis of geographical isolation from other known populations of $B$. m. brevicauda located further south (Rice 1998). B. m. indica were considered nonmigratory and their breeding season is known to lag behind that of other Southern Hemisphere whales by 6 mo (Mikhalev 2000). However, today it remains an open question whether blue whales from the northern Indian Ocean are a separate subspecies from pygmy blue whales (Brownell \& Donahue 1994, Rice 1998, Branch et al. 2007a, Branch \& Mikhalev 2008) because there are as yet no confirmed recognizable behavioural and morphological differences between this and other blue whale populations (Branch et al. 2007a, Branch \& Mikhalev 2008). Given the lack of information regarding $B$. m. indica, we do not consider this subspecies in the present study. Both $B$. m. intermedia and B. m. brevicauda subspecies are presently listed on the IUCN Red List of Threatened Species: the Antarctic blue whale is listed as Critically Endangered (Reilly et al. 2008), while available information on pygmy blue whale is not sufficient for a proper assessment of conservation status (Data Deficient; Cetacean Specialist Group 1996). Indeed, very little information is available on the current status of the subspecies and subpopulations of blue whales, particularly on their distribution, movement and abundance (Branch et al. 2007a). Little information exists on population structure of blue whales, and there is confusion distinguishing between pygmy and Antarctic blue whales. Filling this gap is thus challenging and monitoring of blue whale subspecies and subpopulations is crucial for their management.

As with other baleen whale species, blue whales are supposed to exhibit long seasonal migrations between high-latitude feeding areas and low-latitude wintering areas (Brown 1954, Mackintosh 1966). However, historical catches, recent sightings and acoustic recordings reveal that blue whale subspecies inhabit different regions or latitudes during austral summer (Branch et al. 2007a). Antarctic blue whales generally remain south of the Antarctic Convergence (i.e. south of $52^{\circ}$ to $56^{\circ} \mathrm{S}$ ) and are usually concentrated closer to the ice edge, while the pygmy blue whales are generally found in northerly waters of the Indian Ocean (north of $55^{\circ} \mathrm{S}$ ) and do not seem to migrate to the Antarctic (Ichihara 1966, Kato et al. 1995, Branch et al. 2007a,b). The pygmy blue whale subpopulation of the northwest Indian Ocean has been reported to be resident yearround (Zemsky \& Sazhinov 1982, Mikhalev 2000, Ballance et al. 2001), whereas the sub-Antarctic region subpopulation moves from the western subtropical Indian waters to the sub-Antarctic waters during spring/summer and back again in the autumn (Ichi- hara 1961, Zemsky \& Sazhinov 1982, Best et al. 2003, Miyashita et al. 1995), and the Australian region subpopulation moves along the western coast of Australia in spring/summer (Gill 2002, Rennie et al. 2009) and splits into groups which travel west and east of the continent, retracing these movements during autumn (Zemsky \& Sazhinov 1982). Wintering areas of Antarctic blue whales are not well known despite recently reported occurrence within Antarctic waters (Široviç et al. 2004, 2009) and the northern Indian Ocean (i.e. Diego García; Stafford et al. 2004) from wintertime acoustic recordings. There is a need to better determine the distribution of the blue whale within the southern Indian Ocean in order to assess a possible spatial or temporal segregation between subspecies and subpopulations.

Studying blue whales is difficult because of their wide-ranging distribution, extensive migration and the difficulty distinguishing subspecies or subpopulations based solely on visual sightings. In the Indian and Southern Oceans there are 2, possibly 3 , subspecies Balaenoptera musculus intermedia, B. m. brevicauda and $B . m$. indica - and it is unclear how many subpopulations. The only way to distinguish them is via acoustic monitoring, although little has been done to distinguish among the pygmy type subspecies. Blue whales produce intense (188 $\mathrm{dB}$ re $1 \mu \mathrm{Pa}$ at $1 \mathrm{~m})$, long (up to $20 \mathrm{~s}$ ) and low frequency $(16-100 \mathrm{~Hz}$ ) sounds (McDonald et al. 2006) year-round which propagate over long distances (Široviç et al. 2007, Stafford et al. 2007). Marked geographic variations in blue whale call characteristics have been previously reported and proposed as a tool for determination of subspecies, stocks and populations (reviewed in McDonald et al. 2006). Longterm deployment of passive acoustic recorders has been used to help identify areas of concentration and assess seasonal occurrence of subspecies in the eastern tropical Pacific (Stafford et al. 1999), and these methods should work equally well for Indian and Southern Ocean blue whales. In the Southern Hemisphere, Antarctic blue whales produce unique calls (see Fig. 2a) that have been reported circumpolarly and consist of 3 tonal units that last approximately 26 s, repeated in patterned sequences every 40 to $50 \mathrm{~s}$ over a period of a few minutes or hours (Ljungblad et al. 1998, Široviç et al. 2004, Stafford et al. 2004, Rankin et al. 2005, Samaran et al. 2008). Three other distinct call types have usually been labelled as pygmy blue whale calls and differ according to the location in the Indian Ocean in which they are recorded. The first call type has been recorded in the presence of blue whales off northeast Sri Lanka and has been attributed to the pygmy blue whales of the northwest region of the Indian Ocean (Alling et al. 1991). This Sri Lankan call type (see Fig. 2e) consists of 3 units repeated in pat- 
terned sequences every $210 \mathrm{~s}$. The second call type has been recorded in the presence of pygmy blue whales on the Madagascar Plateau and has been attributed to the pygmy blue whales of the sub-Antarctic region (Ljungblad et al. 1998). This Madagascan call type (see Fig. 2c) consists of 2 long units repeated in patterned sequences every 90 to $100 \mathrm{~s}$ (Samaran et al. 2008). The third call type has been recorded in the presence of pygmy blue whales in southwestern Australian waters (McCauley et al. 2004). This Australian call type (see Fig. 2g) consists of 3 long units repeated in patterned sequences every $180 \mathrm{~s}$. Blue whales also produce downswept short duration (1 to $4 \mathrm{~s}$ ) and frequencymodulated calls (90 to $25 \mathrm{~Hz}$ ) (Thompson et al. 1996). These D calls (see Fig. 2i) have variable characteristics and occur among feeding blue whales, but do not have obvious geographic variation compared to the low-frequency blue whale calls (e.g. Thompson et al. 1996, Oleson et al. 2007). These calls have been recorded in the presence of Antarctic blue whales in the Southern Ocean (Rankin et al. 2005). No acoustic recordings are available for B. m. indica, which adds weight to the uncertainty regarding the status of that blue whale population.

Here, we present the results from the first year-long, continuous acoustic monitoring of blue whales in a former whaling ground in the southern Indian Ocean. At least 2 of the 3 subspecies and 3 subpopulations of blue whales could be identified from acoustic data. The location of the site provides new insights into the distribution and occurrence of Antarctic and pygmy blue whale subpopulations. We report the seasonal occurrence of each subspecies and subpopulation and their temporal overlap, and discuss the ecological implications.

\section{MATERIALS AND METHODS}

Study area. The Crozet Islands $\left(46^{\circ} 25^{\prime} \mathrm{S}, 51^{\circ} 40^{\prime} \mathrm{E}\right)$ are located in the sub-Antarctic part of the southern Indian Ocean between the Subantarctic and Polar Fronts (Fig. 1). Circumpolar fronts are known to be highly productive and attract numerous predators, such as seabirds and other marine mammals (Tynan 1998, Bost et al. 2009). Sub-Antarctic islands are known to be primary pygmy blue whale habitat during summer (Zemsky \& Sazhinov 1982). However, very few blue whale visual observations have been reported during the annual marine mammal sighting surveys conducted during austral summer from the RV 'Marion-Dufresne' in the French Southern Territories since 1978 , and a very low sighting rate (2.9 groups per $1000 \mathrm{~km}$ ) was reported from Japanese scouting vessels in the sub-Antarctic area from 35 to $50^{\circ} \mathrm{S}$ and 30 to

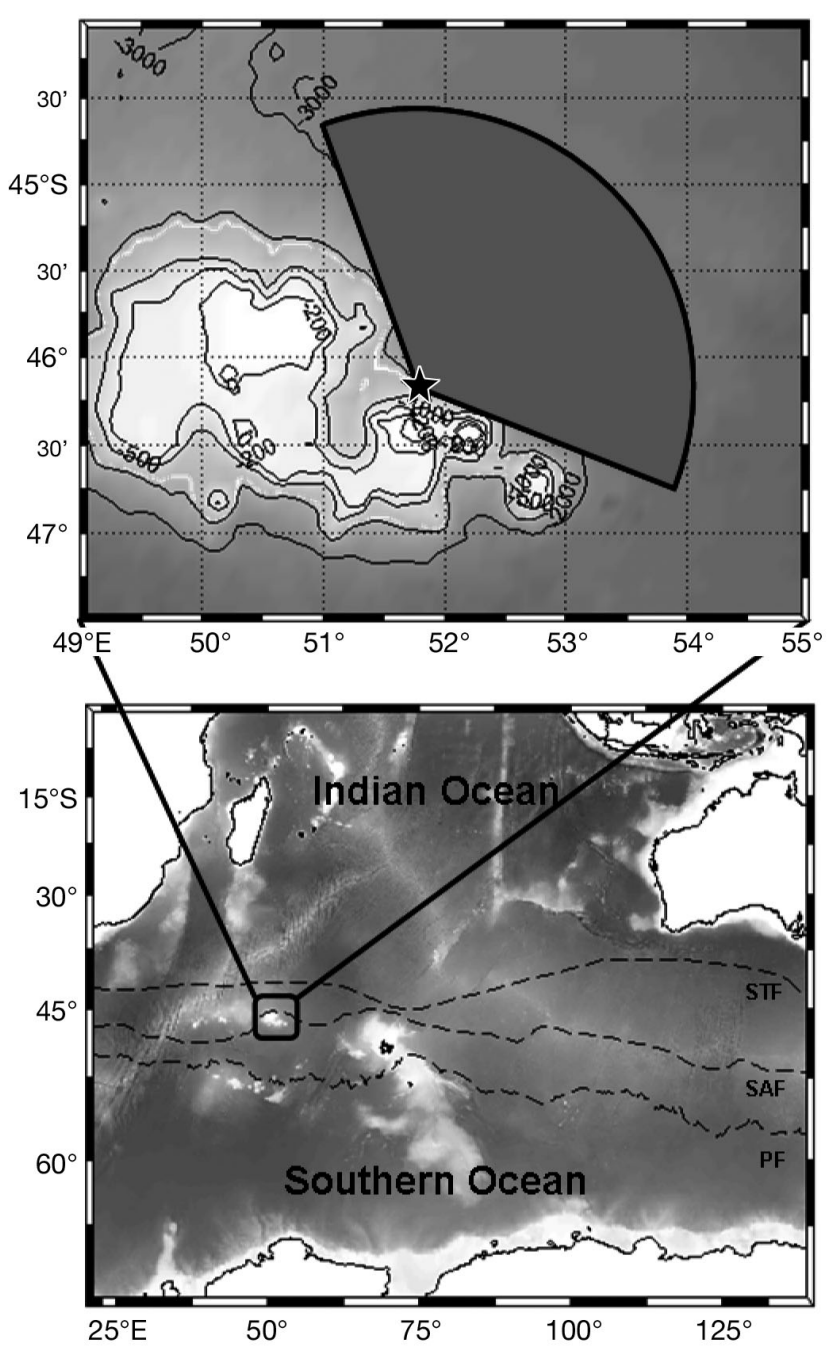

Fig. 1. Location of the hydroacoustic station $(\star)$ of the International Monitoring System near the Crozet Islands. Subtropical (STF), Subantarctic (SAF) and Polar (PF) Fronts are demarcated with dashed lines. The potential call detection area (dark grey area in top panel) is delimited by means of detection range modelling using the range-dependent acoustic model

$100^{\circ} \mathrm{E}$ (Branch et al. 2007a). This suggests that the density of blue whales in these areas remains low postwhaling and that sighting surveys may not be the most efficient means of detecting blue whales in a region plagued by poor weather and low concentrations of animals.

Acoustic data collection. Acoustic data used for the present study were collected from mid-May 2003 to mid-April 2004 from a hydroacoustic station moored near the Crozet Islands in support of the Comprehensive Nuclear Test-Ban Treaty. The station consisted of 2 instruments located on the northern coasts of Possession Island ( $46^{\circ} 09^{\prime} \mathrm{S}, 51^{\circ} 48^{\prime} \mathrm{E}$; Fig. 1). Each instrument consisted of an anchor, a flotation device and a hydro- 
phone. Hydrophones were deployed approximately $2 \mathrm{~km}$ apart. Instruments were moored to the seafloor at depths between 1100 and $1500 \mathrm{~m}$ and hydrophones were suspended near the sound fixing and ranging channel axis at a depth of approximately $300 \mathrm{~m}$. Hydrophones monitored sound continuously at a sampling rate of $250 \mathrm{~Hz}$, coded by 24 bits (S/N: $126.5 \mathrm{~dB}$ ), and a had flat $( \pm 3 \mathrm{~dB})$ frequency response from 1.2 to 102.5 Hz which covered a large variety of sounds: time-variant ambient underwater noise, biological signals (including baleen whale calls) and anthropogenic sounds. Due to the close instrument spacing $(\sim 2 \mathrm{~km})$, for scope of the present study, it was sufficient to analyze data from only one hydrophone.

Acoustic analysis. Spectrograms were scrutinized by an analyst familiar with blue whale calls using AvisoftSASLab Pro software (Fast Fourier Transform, FFT, 1024 points, $93.75 \%$ overlap, Hamming window). Data for each available hour from May 2003 to April 2004 were visually examined for the 4 low-frequency blue whale call types reported in the Southern and Indian Oceans (i.e. Antarctic blue whale call and the 3 pygmy blue whale call types: Sri Lankan, Madagascan and Australian) and for the blue whale D calls based on their similarity to published sounds, as specified above. Only the loudest part of the Sri Lankan call type with pure frequency at about $100 \mathrm{~Hz}$ (see Fig. 2e) and only the harmonic (at $70 \mathrm{~Hz}$ ) of the second part of the Australian call type (see Fig. 2g) were visually detected on our instruments. D calls were only recorded in the presence of Antarctic blue whale calls and pygmy blue whale Madagascan call types. When each subspecies was recorded alone, it was possible to associate the $\mathrm{D}$ call production to the subspecies. When both subspecies were recorded together, association was impossible.

Presence or absence of these sound types was recorded for each hour of data examined ( $=7600 \mathrm{~h}$ ), and the resulting data were pooled by month to show the percentage of recording hours during each month with at least one detection of each sound type. Recognizing that call identification can be somewhat subjective, $20 \%$ of the data were randomly selected and call identifications were verified by a second analyst experienced in identifying whale vocalizations. The resulting data were pooled by month to show the percentage of hours during each month when each call was detected automatically.

When association with subspecies was possible, presence of D calls was reported and a Spearman's rank correlation test was used to test the correlation between $\mathrm{D}$ calls and low frequency calls. We also reported the percentage of hours when D calls were recorded, but association with a subspecies was impossible.

Detection range modelling. To evaluate the maximum detection range over which blue whale calls can be recorded by the hydrophones in the background noise off the Crozet Islands, we used the received level of the call combined with a reliable sound transmission loss model. For the specific context of the study area, the parabolic equation method (range-dependent acoustic model, Collins 1993) was used to estimate propagation loss along the range depth from source to receiver (see details in Samaran 2008, Samaran et al. in press). Taking into account the properties of transmission loss for low-frequency signals, maximum detection range was only modelled for Antarctic blue whale calls. Among the blue whale call types recorded at the station, this type of call has the lowest frequency and highest intensity reported in the literature (Široviç et al. 2007, Samaran et al. 2010) and allows evaluation of the maximum detection range for all blue whale call types recorded at the station. The parabolic equation loss model was configured with the precise characteristics of the biological source (main frequency, received and source level, depth), hydroacoustic station (depth, geographic position) and environment in the study area (background noise, bathymetry, sound speed profiles, ocean bottom composition). The frequency value of the source chosen was $28 \mathrm{~Hz}$, the longest part of the Antarctic blue whale call with the highest intensity (Široviç et al. 2007, Samaran et al. in press). The source level value has been previously estimated for Antarctic blue whales in the study area (Samaran et al. 2010). An automatic method was used to detect and measure the received level of each Antarctic blue whale call recorded. This method used a matched filter process which cross-correlated the acoustic data with synthetic waveforms (templates) defined for Antarctic blue whale calls (based on the limited range of variability in the call; details in Samaran et al. 2008). In the frequency bandwidth of Antarctic blue whale calls (e.g. 17 to $30 \mathrm{~Hz}$ ), this method allowed us to detect calls with a signal-to-noise ratio of up to $-15 \mathrm{~dB}$. Received levels (RMS, in $\mathrm{dB}$ re $1 \mathrm{\mu Pa}^{2} \mathrm{~Hz}^{-1}$ ) were measured for each call detected and the hourly ambient acoustic noise level (in $\mathrm{dB}$ re $1 \mu \mathrm{Pa}^{2} \mathrm{~Hz}^{-1}$ ) received at the hydrophone was also measured in the frequency bandwidth of Antarctic blue whale calls (Samaran et al. in press). To evaluate the maximum detection range over which blue whale calls can be detected, the model was performed using the lowest received level of blue whale call and the lowest value of ambient noise level recorded at the hydrophone.

\section{RESULTS}

Based on modelling results and due to the bathymetry of the area, Antarctic blue whale calls might have been detected at most $180 \mathrm{~km}$ off the northeast part of 
the Crozet Islands (in a restricted area) (Fig. 1). The range for pygmy blue whales should be somewhat less, based on their lower estimated source levels (Samaran 2008, Samaran et al. 2010, in press). The Antarctic and pygmy blue whale Madagascan call types were the most common blue whale calls recorded from the study period in the southwestern Indian Ocean. Antarctic blue whale calls were recorded throughout the year, with less detection during summer months $(<40 \%$ of the hours examined in January; Fig. 2b). From the end of summer to the end of winter, Antarctic blue whale calls were recorded in over $70 \%$ of the hours examined. The pygmy blue whale Madagascan call type was only recorded from the beginning of summer to the beginning of winter (Fig. 2d). The percentage of hours with calls increased during summer and autumn months and decreased to less than $2 \%$ at the beginning of the winter months, with no calls recorded between August and October. Calls occurred in over $96 \%$ of the hours examined in April. Sri Lankan type calls were recorded year-round, but at low numbers, and most detection occurred from mid-spring until mid-autumn (Fig. 2f). Pygmy blue whale Australian type calls were recorded only during 4 mo during summer and early autumn (Fig. 2h).

Seasonal patterns of D calls differed depending upon whether they associated with Antarctic blue whale or pygmy blue whale Madagascan call types (Fig. 2b,d). The percentage of hours with D calls recorded in association with Antarctic blue whales calls was highly seasonal, with an increase during winter and midspring and a decrease during summer (Fig. 2b). No relationship was found between the percentage of hours with Antarctic blue whale calls and the percentage of hours with $\mathrm{D}$ calls recorded in association with these calls (Spearman's rank test, $r_{S}=0.07, n=12, p>$ 0.05). The percentage of hours with $\mathrm{D}$ calls recorded in association with pygmy blue whale Madagascan type calls was high at the beginning of summer (Fig. 2d). There was a positive relationship between the percentage of hours with pygmy blue whale Madagascan type calls and the percentage of hours with D calls recorded in association with these calls $\left(r_{S}=0.9, n=12, p<0.01\right)$. The percentage of hours with D calls when no association with a given subspecies could be made (Fig. 2h) was low (18\% of the hours with D calls), and this situation occurred when the 2 subspecies were simultaneously present during fall and summer.

\section{DISCUSSION}

The results reported in the present study arise from the first effort to continuously acoustically monitor blue whale calls in a former whaling area in the sub-Antarc- tic (Ichihara 1961). Our data demonstrate that different blue whale subspecies and subpopulations occurred sympatrically at least during austral summer and autumn months in the Crozet area, emphasizing the importance of this region for blue whale populations. All calling whales were located in a region to the northeast, and within a maximum distance of $180 \mathrm{~km}$, of the Crozet Islands.

\section{Antarctic blue whales}

The seasonal cycle of the Antarctic blue whale has historically been defined by a migration pattern between high-latitude summer feeding areas and lowlatitude wintering areas (Brown 1954, Mackintosh 1966). Whaling data have indicated the presence of Antarctic blue whales during summer primarily south of the Antarctic Convergence and, more specifically, close to the ice edge (Kasamatsu et al. 1996, Branch et al. 2007a). However, as the majority of commercial whaling occurred during the summer months (Mackintosh 1965), potential movements, winter distribution and breeding grounds of Antarctic blue whales cannot be properly assessed from these data. Recent acoustic studies have detected Antarctic blue whale calls at higher latitudes year-round; however, call detections decrease during the winter months (Široviç et al. 2004, 2009). A few acoustic records at mid-and low-latitudes during winter months suggest that some part of the Antarctic blue whale population keeps migrating further north in the Indian Ocean (Stafford et al. 2004). Our results suggest for the first time a year-round presence of Antarctic blue whales to the north of the Polar Front. The high level of call detections especially during winter months (up to $70 \%$ of examined hours contained calls) raises the question of a mid-latitude Antarctic blue whale winter breeding ground. The presence of calling Antarctic blue whales during winter and spring could also indicate either a time-lagged migration, or that some individuals skip migration to feed in sub-Antarctic waters while others migrate to Antarctic waters. Antarctic blue whale calls are still detected at Crozet during the summer Antarctic feeding period. In this context, the waters around Crozet could represent a summer feeding ground. Indeed, during the end of winter and spring months, Antarctic blue whale calls detected at Crozet are associated with D calls. In a recent study of the behavioural contexts of eastern North Pacific blue whale call production, Oleson et al. (2007) found that the downswept D calls were generally produced during short breaks from feeding. The decreasing number of detections of both Antarctic blue whale calls and D calls from November to January in the present study suggests that a part of the popula- 

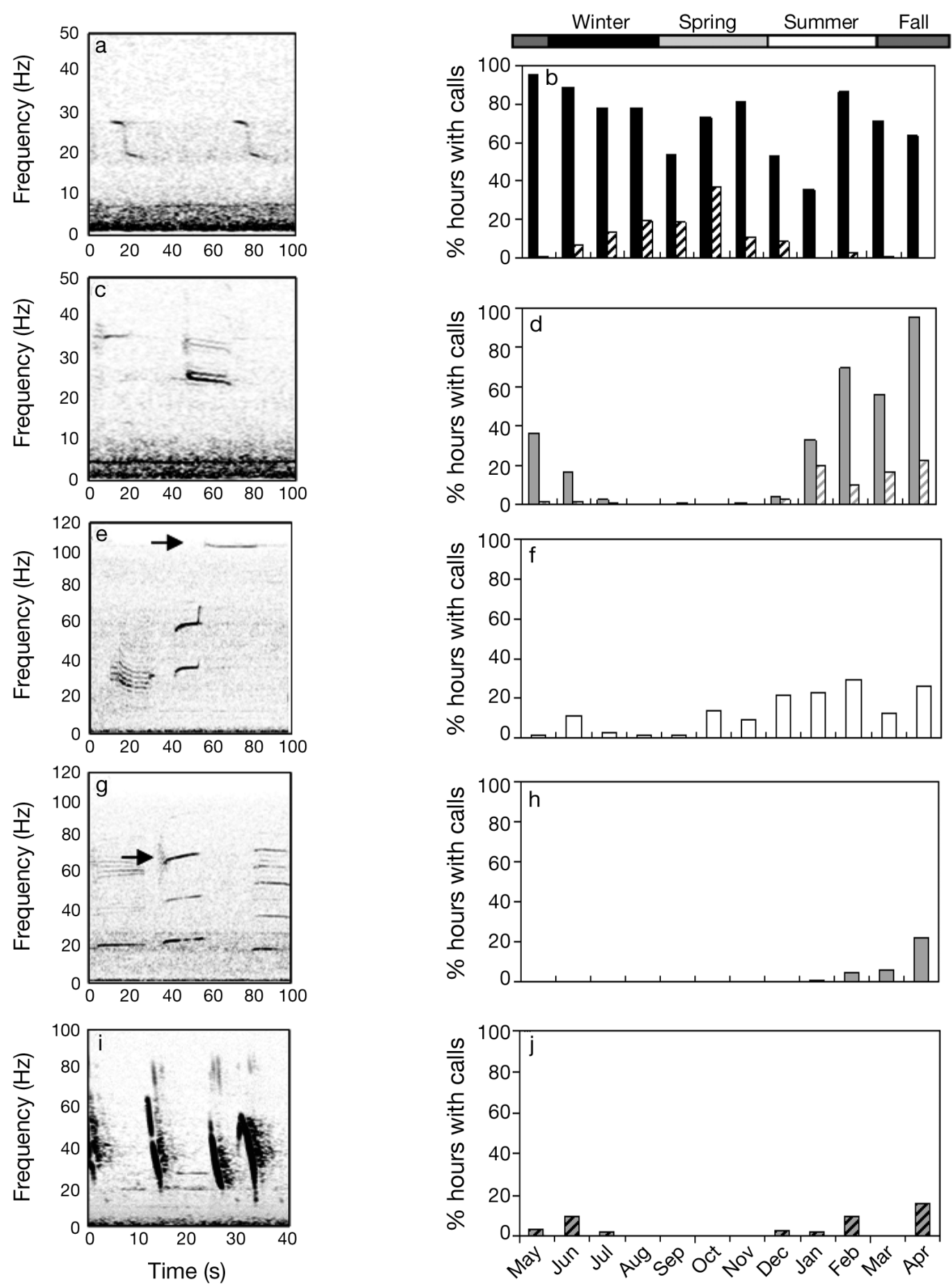

Fig. 2. Spectrogram of blue whale calls and histograms of seasonal call patterns detected at the hydroacoustic station from May 2003 to April 2004. Bars represent proportion of hours in which calls were detected per month. (a) 2 Antarctic blue whale calls (Fast Fourier Transform, FFT, 1024 points, 93.75\% overlap, Hanning window); (b) seasonal pattern of Antarctic blue whale calls (black) and D calls recorded in association with Antarctic blue whale calls (hatched); (c) 1 pygmy blue whale Madagascan call type (FFT 1024 points, 93.75\% overlap, Hanning window); (d) seasonal pattern of pygmy blue whale Madagascan type calls (grey) and D calls recorded in association with pygmy blue whale Madagascan type calls (hatched); (e) 1 pygmy blue whale Sri Lankan call type (FFT 512 points, 93.75\% overlap, Hanning window), arrow represents the part of the call visually detected on the spectrogram; (f) seasonal pattern of pygmy blue whale Sri Lankan type calls; (g) 1 pygmy blue whale Australian call (FFT 512 points, $93.75 \%$ overlap, Hanning window), arrow represents the part of the call visually detected on the spectrogram; (h) seasonal pattern of pygmy blue whale Australian type calls; (i) D calls (FFT 512 points, 93.75\% overlap, Hamming window);

(j) seasonal pattern of D calls when no clear association with blue whale subspecies was possible 
tion of the Antarctic blue whales present around Crozet may have reduced feeding activities and left this area during summer. The absence of correlation between D calls and Antarctic blue whales throughout the year suggests that this area is also used for other purposes, such as a migratory pathway. Crozet could be on the migration route of blue whales from Antarctica to the northern Indian Ocean.

\section{Pygmy blue whale subpopulations}

Pygmy blue whales were identified for the first time from catches taken near Kerguelen Island and were well known to be present in the sub-Antarctic at least during the summer months (Ichihara 1966). Results of the present study reveal that this subspecies continues to occupy its historical range. The strong relationship between pygmy blue whale Madagascan type calls and D calls suggests that this subspecies visits Crozet waters mainly to feed, supporting the hypothesis that this region is a pygmy blue whale feeding ground. The absence of call detection during winter and spring months suggests either a cessation of calling activity or, more plausibly, that animals leave this area and move north. Based on visual observations, historical catches and acoustic detections (Zemsky \& Sazhinov 1982, Ljungblad et al. 1998, Best et al. 2003), pygmy blue whales have been reported on the Madagascar Plateau (Best et al. 2003), suggesting migrations of whales between sub-Antarctic and subtropical waters.

The detection of the pygmy blue whale Australian type call during autumn months in Crozet waters shows that the distribution range of this subpopulation is substantially larger than previously thought (Gill 2002, McCauley et al. 2004, Rennie et al. 2009). Pygmy blue whales from the Australian region are known to inhabit waters west to Amsterdam and St Paul Islands at least during winter months (Zemsky \& Sazhinov 1982). Seasonal occurrence of blue whales has been previously found in the Perth Canyon off Western Australia and in the upwelling zone off the southeastern coast (Gill 2002, Rennie et al. 2009). Our results suggest longitudinal movements from east to west, probably along the productive Subantarctic and Subtropical Fronts of the Indian Ocean (Moore \& Abbott 2000). More data are needed in future studies to more precisely assess the distribution and interannual differences in longitudinal movements of the pygmy blue whale subpopulations of the Australian region.

On a few occasions, pygmy blue whale Sri Lankan type calls were detected during spring/summer in the Crozet region. Previously, the only published descriptions of these calls were from the northern part of the Indian Ocean (Alling et al. 1991). However, our results demonstrate that, while blue whales producing the Sri Lankan type calls are generally thought to have a more northerly distribution, they venture into sub-Antarctic waters, at least during late summer and early fall when other subpopulations of pygmy blue whales are likely to feed in this area. However, the low percentage of hours with Sri Lankan type calls suggests that few calling whales from this subpopulation are present within the Crozet area.

\section{Importance of the sub-Antarctic area for blue whales}

Sub-Antarctic and frontal areas are highly productive during austral summer (Moore \& Abbott 2000) due to the presence of important zooplankton biomass and pelagic fishes (mainly myctophids; Pakhomov et al. 1994). Oceanographic characteristics off Crozet are likely to generate favourable trophic conditions for migrating blue whales that can exploit this seasonally productive mid-latitude area (Pollard et al. 2007). Stomach analysis of past pygmy blue whale catches has revealed that the main blue whale prey in this area consisted of a broad range of prey, especially krill (Euphausia frigida and E. vallentini) as well as myctophids Myctophum punctatum (Pervushin 1968).

In the Southern Hemisphere, mid-latitude blue whale feeding grounds have already been reported in southern Chilean waters (Hucke-Gaete et al. 2004) and in western and southern Australian coastal waters (Gill 2002, Rennie et al. 2009) based on visual sightings. But unlike our acoustic approach, no subspecific identity of blue whales could be clearly attributed; however, these authors suggest that these feeding grounds were probably used by pygmy blue whales, considering the northerly location of both sites relative to the Antarctic Convergence. Our results suggest that the 2 main feeding grounds reported to date (Chile and Australia) could be augmented by a third area in the southwestern Indian Ocean exploited by 4 different blue whale stocks, where Antarctic and pygmy blue whales are sympatric during summer and autumn months.

\section{CONCLUSIONS}

Given the relative paucity of blue whale sighting data from the Southern and Indian Oceans, these new data highlight the effectiveness of using passive acoustic monitoring to provide information relevant to the seasonal occurrence and movements of blue whales in this remote area. The results improve our understanding of the migration and distribution patterns of blue whale subspecies and subpopulations and 
contribute information that could be helpful to assess the conservation status and management of these species. This unusual blue whale diversity within an important past sub-Antarctic whaling ground highlights the importance of Crozet waters as a blue whale hotspot. Previous studies have used the characteristics of calls to determine the seasonal presence and movement of blue whales through a region (e.g. Stafford et al. 1999), including the possibility of populations mixing within a region (Stafford et al. 2001). Our acoustic study shows that we cannot establish the identity of blue whale populations on the basis of latitude alone. Consequently, feeding ground segregation used as a proxy for subspecies identity is clearly not applicable to the Crozet region. Additional continuous, basinscale acoustic monitoring throughout the Indian and Southern Oceans is needed to better understand the distributions of different blue whale subspecies and subpopulations; this information is critical to the future conservation and management of Southern Hemisphere blue whales.

Acknowledgements. We thank Y. Cansi and G. Ruzié who provided access to the data; the Bioacoustic team of the Centre de Neurosciences de Paris-Sud lab, especially I. Charrier who provided access to Avisoft SASLab Pro software; P. F. Piserchia for access and helping with Interface HommeMachine Range-dependent Acoustic Model (IHM RAM) for the detection distance range modelling; $\mathrm{C}$. Cotté for his helpful comments on the different stages of the manuscript; and A. Scheffer for improving the English. This work was supported by the French Ministry of Ecology, the Association DIRAC (France) and the Commissariat à l'Energie Atomique. The IMS hydrophone data were available through the Commissariat à l'Energie Atomique (CEA) under contract (CEA no.169-C-BEFI, CNRS no. 781513). The information released in this paper conforms to the conditions set forth in this contract. We thank B. Brownell and 3 anonymous referees for their helpful comments that substantially improved earlier versions of this manuscript. This work represents a portion of F.S.'s PhD.

\section{LITERATURE CITED}

Alling A, Dorsey EM, Gordon JCD (1991) Blue whales (Balaenoptera musculus) off the northeast coast of Sri Lanka: distribution, feeding and individual identification. UNEP Mar Mamm Tech Rep 3:247-258

Ballance LT, Anderson RC, Pitman RL, Stafford K, Shaan A, Waheed Z, Brownell RL Jr (2001) Cetacean sightings around the Republic of the Maldives, April 1998. J Cetacean Res Manag 3:213-218

Best PB, Rademeyer RA, Burton C, Ljungblad D and others (2003) The abundance of blue whales on the Madagascar Plateau, December 1996. J Cetacean Res Manag 5: 253-260

Blyth E (1859) On the great rorqual of the Indian Ocean, with notices of other cetals, and of the Syrenia or marine pachyderms. J Asiatic Soc Bengal 28:481-498

Bost CA, Cotte C, Bailleul F, Cherel Y and others (2009) The importance of oceanographic fronts to marine birds and mammals of the southern oceans. J Mar Syst 78:363-376 Branch TA, Mikhalev YA (2008) Regional differences in length at sexual maturity for female blue whales based on recovered data from illegal Soviet whaling data. Mar Mamm Sci 24:690-703

Branch TA, Matsuoka K, Miyashita T (2004) Evidence for increases in Antarctic blue whales based on Bayesian modelling. Mar Mamm Sci 20:726-754

Branch TA, Stafford KM, Palacios DM, Allison C and others (2007a) Past and present distribution, densities and movements of blue whales in the Southern Hemisphere and northern Indian Ocean. Mammal Rev 37:116-175

Branch TA, Abubaker EMN, Mkango S, Butterworth DS (2007b) Separating southern blue whale subspecies based on length frequencies of sexually mature females. Mar Mamm Sci 23:803-833

Brown SG (1954) Dispersal in blue and fin whales. Discov Rep 26:355-384

Brownell RL, Donahue MA (1994) Southern Hemisphere pelagic whaling for pygmy blue whales: review of catch statistics. Paper SC/46/SH6, International Whaling Commission, Cambridge

Cetacean Specialist Group (1996) Balaenoptera musculus ssp. brevicauda. In: IUCN (ed) IUCN Red List of Threatened Species. Version 2010.2. Available at www.iucnredlist.org

Clapham PJ, Young SB, Brownell RL Jr (1999) Baleen whales: conservation issues and the status of the most endangered populations. Mammal Rev 29:37-62

Collins MD (1993) A split-step Padé solution for the parabolic equation method. J Acoust Soc Am 93:1736-1742

Gambell R (1976) World whale stocks. Mammal Rev 6:41-53

Gill PC (2002) A blue whale (Balaenoptera musculus) feeding ground in a southern Australian coastal upwelling zone. J Cetacean Res Manag 4:179-184

Hucke-Gaete R, Osman LP, Moreno CA, Findlay KP, Ljunglblad DK (2004) Discovery of a blue whale feeding and nursing ground in southern Chile. Biol Lett 271: 170-173

Ichihara T (1961) Blue whales in the waters around Kerguelen Island. Norsk Hvalfangst-Tidende 50:1-20

Ichihara T (1966) The pygmy blue whale, Balaenoptera musculus brevicauda, a new subspecies from the Antarctic. In: Norris KS (ed) Whales, dolphins, and porpoises. University of California Press, Berkeley, CA, p 79-111

Kasamatsu F, Joyce GG, Ensor P, Mermoz J (1996) Current occurrence of baleen whales in Antarctic waters. Rep Int Whal Comm 47:293-304

Kato H, Miyashita T, Shimada H (1995) Segregation of the two sub-species of the blue whale in the Southern Hemisphere. Rep Int Whal Comm 45:273-283

Kawamura A (1994) A review of baleen whale feeding in the Southern Ocean. Rep Int Whal Comm 44:261-271

LeDuc RG, Dizon AE, Goto M, Pastene LA, Kato H, Nishiwaki S, Brownell RL Jr (2007) Patterns of genetic variation in Southern Hemisphere blue whales, and the use of assignment test to detect mixing on the feeding grounds. J Cetacean Res Manag 97:3-80

Ljungblad DK, Clark CW, Shimada H (1998) A comparison of sounds attributed to pygmy blue whales (Balaenoptera musculus brevicauda) recorded south of the Madagascar Plateau and those attributed to 'true' blue whales (Balaenoptera musculus) recorded off Antarctica. Rep Int Whal Comm 48:439-442

> Lockyer C (1976) Body weights of some species of large whales. ICES J Mar Sci 36:259-273

Mackintosh NA (1965) The stocks of whales. Fishing News, London 
Mackintosh NA (1966) Distribution of southern blue and fin whales. In: Norris KS (ed) Whales, dolphins, and porpoises. University of California Press, Berkeley, CA, p 125-144

McCauley R, Bannister J, Burton C, Jenner C, Rennie S, Kent CS (2004) Western Australian exercise area blue whale project. Final summary report. Report R2004-29, Project 350. Centre for Marine Science and Technology, Curtin University of Technology, Perth

McDonald MA, Hildebrand JA, Mesnick SL (2006) Biogeographic characterization of blue whale song worldwide: using song to identify populations. J Cetacean Res Manag 8:55-65

Mikhalev YA (2000) Whaling in the Arabian Sea by the whaling fleets Slava and Sovetskaya Ukraina. In: Yablokov AV, Zemsky VA (eds) Soviet whaling data (1949-1979). Center for Russian Environmental Policy and Russian Marine Mammals Council, Moscow, p 141-181

Miyashita T, Kato H, Kasuya T (1995) Worldwide map of cetacean distribution based on Japanese sighting data, Vol. 1. National Research Institute of Far Seas Fisheries, Shimizu

Moore JK, Abbott MR (2000) Phytoplankton chlorophyll distributions and primary production in the Southern Ocean. J Geophys Res 105:28709-28722

Oleson EM, Calambokidis J, Burgess WC, McDonald MA, LeDuc CA, Hildebrand JA (2007) Behavioral context of call production by eastern North Pacific blue whales. Mar Ecol Prog Ser 330:269-284

Pakhomov EA, Perissinotto R, McQuaid CD (1994) Comparative structure of the macrozooplankton/micronekton communities of the subtropical and Antarctic polar fronts. Mar Ecol Prog Ser 111:155-169

Pervushin H (1968) Observations of behaviour and feeding of whale-bone whales in the area of the Crozet Islands. Okeanologiya 8:139-145

Pollard RT, Venables HJ, Read JF, Allen JT (2007) Large-scale circulation around the Crozet Plateau controls an annual phytoplankton bloom in the Crozet Basin. Deep-Sea Res II 54:1915-1929

Rankin S, Ljungblad D, Clark C, Kato H (2005) Vocalisations of Antarctic blue whales, Balaenoptera musculus intermedia, recorded during the 2001/2002 and 2002/2003 IWC/SOWER circumpolar cruises, Area V, Antarctica. J Cetacean Res Manage 7:13-20

Reilly SB, Bannister JL, Best PB, Brown M and others (2008) Balaenoptera musculus ssp. intermedia. In: IUCN (ed) IUCN Red List of Threatened Species. Version 2010.2. Available at www.iucnredlist.org

Rennie S, Hanson CE, McCauley RD, Pattioratchi C and others (2009) Physical properties and processes in the Perth Canyon, Western Australia: links to water column production and seasonal pygmy blue whale abundance. J Mar Syst 77:21-44

Editorial responsibility: Andrew Read, Beaufort, North Carolina, USA
Rice DW (1998) Marine mammals of the world: systematics and distribution. Allen Press, Lawrence, KS

Samaran F (2008) Analyse des signaux acoustiques d'origine biologique enregistrés dans l'Océan Indien: Implication dans le recensement et le suivi des mouvements saisonniers des cétacés. PhD thesis, University of La Rochelle, La Rochelle

Samaran F, Adam O, Motsch JF, Guinet C (2008) Definition of the Antarctic and pygmy blue whale call templates. Application to fast automatic detection. Can Acoust 36:93-102

Samaran F, Adam O, Motsch JF, Cansi Y, Guinet C (2010) Source level estimation of two blue whale subspecies in southwestern Indian Ocean. J Acoust Soc Am 127: 3800-3808

Samaran F, Adam O, Guinet C (in press) Detection range modeling of blue whale calls in southwestern Indian Ocean. Appl Acoust, doi:10.1016/j.apacoust.2010.05.014

Široviç A, Hildebrand JA, Wiggins SM, McDonald MA, Moore SE, Thiele D (2004) Seasonality of blue and fin whale calls and the influence of sea ice in the western Antarctic Peninsula. Deep-Sea Res II 51:2327-2344

> Široviç A, Hildebrand JA, Wiggins SM (2007) Blue and fin whale call source levels and propagation range in the Southern Ocean. J Acoust Soc Am 122:1208-1215

Široviç A, Hildebrand JA, Wiggins SM, Thiele D (2009) Blue and fin whale acoustic presence around Antarctica during 2003 and 2004. Mar Mamm Sci 25:125-136

Stafford KM, Nieukirk SL, Fox CG (1999) Low-frequency whale sounds recorded on hydrophones moored in the eastern tropical Pacific. J Acoust Soc Am 106:3687-3698

Stafford KM, Nieukirk SL, Fox CG (2001) Geographic and seasonal variation of blue whale calls in the North Pacific. J Cetacean Res Manag 3:65-76

Stafford KM, Bohnenstiehl DR, Tolstoy M, Chapp E, Mellinger DK, Moore SE (2004) Antarctic type blue whale calls recorded at low latitudes in the Indian and eastern Pacific Oceans. Deep-Sea Res I 51:1337-1346

Stafford KM, Mellinger DK, Moore SE, Fox CG (2007) Seasonal variability and detection range modeling of baleen whale calls in the Gulf of Alaska, 1999-2002. J Acoust Soc Am 122:3378-3390

Thompson PO, Findley LT, Vidal O, Cummings WC (1996) Underwater sounds of blue whales, Balaenoptera musculus, in the Gulf of California, Mexico. Mar Mamm Sci 12: 288-292

Tynan CT (1998) Ecological importance of the southern boundary of the Antarctic Circumpolar Current. Nature 392:708-710

Zemsky VA, Sazhinov EG (1982) Distribution and current abundance of pygmy blue whales. In: Gurevich VS, Arsenév VA, Donahue MA, Brownell RL Jr (eds) Marine mammals. Southwest Fisheries Science Center Administrative Report LJ-94-02. All-Union Research Institute of Marine Fisheries and Oceanography, Moscow, p 53-70

Submitted: November 4, 2009; Accepted: July 1, 2010

Proofs received from author(s): August 2, 2010 